\title{
DETERMINAN TINGKAT SUKU BUNGA PINJAMAN DI INDONESIA TAHUN 1983 - 2002
}

\author{
Taufik Kurniawan ${ }^{1)}$
}

\begin{abstract}
Abstraksi
This paper analyzes the role of international interest rate, money supply, inflation, SBI rate (Sertifikat Bank Indonesia) and GDP on the lending rate. We use the Error Correction Model on Indonesian yearly data from 1983 - 2002 and confirm the significant of these explanatory variables as the determinant of short and long term credit lending rates.

These findings conforms the necessity for Bank Indonesia as monetary authority to take into account the external factors and support the integration of domestic and foreign financial market.
\end{abstract}

Keyword: Error Correction Model, Interest rate, Financial market, Money Supply, Lending rate. JEL: C22, E44, E51

1 Penulis adaIah Mahasiswa Peraih Beasiswa Penelitian Ekonomi dan Moneter Kerja Sama Bank Indonesia dan Fakultas Ekonomi Universitas Negeri Sebelas Maret Surakarta 


\section{PENDAHULUAN}

Deputi Senior Gubernur Bank Indonesia (BI) Anwar Nasution mengatakan Bank Indonesia mengimbau kepada perbankan untuk menurunkan suku bunga pinjamannya berkaitan dengan terus turunnya Sertifikat Bank Indonesia (SBI). Secara teori bahwa tingkat suku bunga pinjaman merupakan gabungan dari jumlah cost of fund ditambah biaya intermediasi dan biaya resiko macet (Solopos, Jum'at 27 Juni 2003).

Akhir-akhir ini banyak tuntutan dari para pelaku bisnis (pengusaha) dan juga pakar ekonomi yang menuntut agar Bank Indonesia selaku penguasa moneter mempengaruhi suku bunga deposito dan juga suku bunga pinjaman berkaitan dengan turunnya SBI agar dapat meningkatkan / mengembangkan kembali sektor riil lewat kegiatan investasinya. Tetapi tuntutan itu belum atau baru sedikit dipenuhi oleh Bank Indonesia, karena mungkin Bank Indonesia melihat banyak faktor yang perlu dipertimbangkan untuk mempengaruhi suku bunga khususnya suku bunga pinjaman dalam arti nominal.

Banyak negara berkembang telah melaksanakan deregulasi keuangannya dengan cara menghapuskan pagu kredit dan tingkat bunga, misalnya Korea, Malaysia, Sri langka, Filipina, dan Indonesia. Tujuan utama deregulasi keuangan ini seperti deregulasi ekonomi pada umumnya adalah mendorong efisiensi dan pertumbuhan ekonomi. Salah satu tujuan deregulasi adalah mempercepat proses berlangsungnya pendalaman finansial. Pendalaman finansial (financial deep) menunjukkan seberapa jauh sistem finansial terutama sektor perbankan dapat menjangkau masyarakat penabung dan mengalokasikan dana tersebut kepada sektor usaha dan pengguna dana yang paling produktif dan efisien.

Sektor keuangan mempunyai peranan yang penting, bukan hanya sebagai perantara finansial tetapi juga sebagai pihak yang membatasi, menilai dan mendistribusikan resiko yang berkaitan dengan berbagai kegiatan finansial. Pada mekanisme pasar, peranan ini memungkinkan terjadinya keseimbangan antara keuntungan yang diperoleh dengan resiko yang dihadapi. Pendalaman finansial menjamin terjadinya biaya transaksi yang makin rendah, distribusi resiko yang semakin optimal, alokasi dana yang semakin terarah pada pilihan investasi yang terbaik. Dengan demikian pendalaman finansial mendorong peningkatan efisiensi ekonomi dan berjalan seiring dengan perkembangan ekonomi.

Di beberapa negara ASEAN seperti Malaysia, Singapura, Thailand, Filipina, dan Indonesia, perkembangan pendalaman finansial kelihatan menonjol setelah negara-negara tersebut melakukan deregulasi sistem finansialnya. Sebelum adanya deregulasi, sistem finansial negara-negara tersebut ditandai oleh banyaknya peraturan yang kurang mendorong terjadinya pendalaman finansial seperti penentuan tingkat bunga oleh otoritas moneter, 
penetapan pagu kredit, cadangan wajib minimum yang tinggi. Tingkat bunga yang ditetapkan akan cenderung jauh di bawah tingkat bunga keseimbangan dan tingkat inflasi. Dengan demikian, laju inflasi jauh lebih besar daripada tingkat bunga nominal sehingga tingkat bunga rill menjadi negatif. Hal ini dapat menimbulkan distorsi dalam sistem keuangan karena kurangnya mobilisasi dana. Sistem ini juga mengganggu efisiensi pembangunan sistem perbankan. Bank-bank sangat tergantung pada dana dari Bank Indonesia dan tidak dapat mengatur dananya secara efisien.

Tingginya suku bunga pada September 1988 menjadi sejarah tersendiri. Dimulai dengan pernyataan Prof Mohammad Sadli, kemudian Gubemur BI Adrianus Mooy, tentang perlunya perbankan menekan lagi tingkat suku bunga yang dinilai sangat tinggi dan tidak mampu menggairahkan investasi. Penyebab utamanya tingginya suku bunga bank pada waktu itu adalah mahalnya biaya memperoleh dana sendiri.Sebagian besar dana bank diperoleh dari deposito dengan tingkat bunga berada diatas 15 - $21 \%$, baik untuk jangka waktu 1 bulan, 3 bulan, 6 bulan, maupun 12 bulan. Melihat bunga deposito yang demikian tinggi, wajar jika bunga kredit pun sangat tinggi karena biaya intermediasi dari bank. Biaya tersebut antara lain biaya overheat, biaya resiko, dan marjin laba yang jumlahnya masih sekitar $4 \%$, berarti besar bunga kredit pada waktu itu diperkirakan antara 19,5\% sampai $25 \%$ (Sasongko Tedjo, 1994 : 110).

Pengalaman buruk dibidang moneter terulang lagi bahkan lebih buruk, yaitu saat krisis ekonomi dan moneter menimpa bangsa-bangsa Asia termasuk Indonesia pada tahun 1997 - 1998. Pada periode bulan Juli - Agustus 1997 pemerintah menerapkan kebijakan empat kali menaikkan tingkat suku bunga SBI dari bulan Agustus sebesar $7 \%$ menjadi $30 \%$ dalam setahun. Pergerakan suku bunga SBI menjadi tolok ukur bagi tingkat suku bunga lainnya. Sehingga kenaikan suku bunga SBI ini dengan sendirinya mendorong kenaikan suku bunga dana antar bank dan suku bunga deposito. Kenaikan suku bunga deposito akhimya mengakibatkan kenaikan suku bunga pinjaman di bank-bank, terutama karena sebelumnya sudah ada peraturan bahwa tingkat suku bunga di bank komersial ditetapkan 150 \% diatas suku bunga SBI. Suku bunga perbankan untuk deposito dan pinjaman (kredit) di Indonesia adalah tertinggi di kawasan ASEAN bahkan seluruh dunia (Tulus T.H. Tambunan: 1998: 114).

Beberapa literatur penelitian tentang tingkat suku bunga seperti tingkat bunga dan faktor-faktor penentunya (Boediono 1991, p.18), interest rate determination independen developing countries, a conceptual framework (Edward, Sebastian dan Mohsin S. Khan 1985, p.123), Regresi Linear Lancung dalam Analisa Ekonomi : Studi Kasus Permintaan Deposito Dalam Valuta Asing di Indonesia (Insukindro 1991, p.15), Suku Bunga Diturunkan, 
Investasi Akan Meningkat? (Iswardono SP 1999, p. 34), Kinerja dan Fungsi Intermediasi Perbankan Pasca Krisis dan Otonomi Daerah (Juda Agung, 2000, p.45), Sejarah Pemikiran Ekonomi : Teori Bunga (Soewito 94, p.I5)

Dengan mengacu pada fenomena buruk tahun 1988 dan 1998 serta sekarang dan juga penjelasan dari Gubernur Bank Indonesia diatas, Penulis mencoba mengembangkan spesifikasi model untuk menelusuri determinan tingkat suku bunga pinjaman di Indonesia tahun 1983 -2002. Faktor-faktor yang mempengaruhi tingkat suku bunga pinjaman meliputi suku bunga internasional SIBOR, jumlah uang beredar, inflasi, suku bunga Sertifikat Bank Indonesia dan Produk Domestik Bruto baik untuk jangka panjang maupun jangka pendek. Dengan mengetahui determinan tingkat suku bunga pinjaman tersebut, maka diharapkan mengetahui perilaku pergerakan suku bunga pinjaman di Indonesia pada kurun waktu 1983 - 2002.

\section{TINJAUAN TEORITIS}

\section{II.1. Teori Suku Bunga Secara Makro}

Pengertian dasar dari teori tingkat suku bunga yaitu harga dari penggunaan uang untuk jangka waktu tertentu. Bunga merupakan imbalan atas ketidaknyamanan karena melepas uang, dengan demikian bunga adalah harga kredit. Tingkat suku bunga berkaitan dengan peranan waktu didalam kegiatan-kegiatan ekonomi. Tingkat suku bunga muncul dari kegemaran untuk mempunyai uang sekarang.

Teori klasik menyatakan bahwa bunga adalah harga dari loanable funds (dana investasi) dengan demikian bunga adalah harga yang terjadi di pasar dan investasi. Menurut teori Keynes tingkat bunga merupakan suatu fenomena moneter. Artinya tingkat bunga ditentukan oleh penawaran dan permintaan akan uang (ditentukan di pasar uang).

\section{II.2. Teori Suku Bunga (pinjaman) Secara Mikro}

Dalam industri berbankan yang sangat kompetitif, penentuan tingkat bunga kredit menjadi suatu alat persaingan yang sangat strategis. Bank-bank yang mampu mengendalikan pokok dalam penentuan tingkat bunga kredit (lending rate) akan mampu menetukan bunga kredit yang lebih rendah dibandingkan dengan bank-bank lainnya.

\section{II.2.1. Cost of Loanable Funds}

a. Menetapkan tingkat bunga yang akan dibayarkan kepada deposan. 
b. Menghitung komposisi sumber dana.

c. Memperhatikan ketentuan tentang reserve requirement (RR).

d. Menghitung biaya dengan dana efektif dengan rumus :

$$
\frac{100 \%}{100 \%-R R} \times \text { Tingkat Bunga }
$$

e. Menghitung kontribusi biaya dana dengan rumus :

Komposisi Dana x Biaya Dana Efektif

f Menjumlah seluruh kontribusi biaya dana untuk memperoleh tingkat cost of loanable funds.

\section{II.2.2. Overhead cost}

a. Dikeluarkan oleh bank dalam menjalankan kegiatannya.

b. Biaya-biaya yang termasuk dalam overhead cost ditanggung oleh seluruh jumlah aktiva yang menghasilkan pendapatan atau total aktiva produktif (total earning assets).

Dengan demikian perhitungan persentase overhead cost dapat dinyatakan sebagai berikut :

$$
\text { Overhead Cost }=\frac{\text { Total Biaya (di luar biaya dana) }}{\text { Total Earning Assets }} \times 100 \%
$$

Dihadapkan pada berbagai kondisi persaingan yang ada, dalam praktek perbankan sehari-hari pada eksekutif menempatkan kebijakan untuk memasang tarif dalam perhitungan overhead cost antara $2 \%$ sampai dengan $4 \%$.

\section{II.2.3. Risk factor}

Risk Factor adalah komponen dalam menentukan lending rate yang sangat mempertimbangkan kemungkinan terjadinya kredit bermasalah termasuk kredit macet.

Risk factor dapat dihitung dengan rumus sebagai berikut :

$$
\text { Risk Factor }=\frac{\text { Biaya Penyisihan Cadangan Penghapusan Kredit }}{\text { Total Kredit yang Diberikan }} \times 100 \%
$$


Dalam praktek perbankan sehari-hari, besarnya risk factor berkisar 1 hingga 2,5\%, dengan mempertimbangkan jenis kredit yang akan diberikan, keyakinan akan terjadinya risiko kredit, volume kredit yang diberikan, serta kondisi persaingan yang ada.

\section{II.2.4 Spread}

Spread atau biasa juga disebut dengan net margin adalah pendapatan bank yang utama dan akan menentukan besarnya pendapatan bersih (net income) bank. Penentuan tinggi rendahnya spread tergantung bagaimana pihak bank serta target market-nya. Untuk mengelompokan jenis industri serta peringkat usaha bank merupakan salah satu pertimbangan untuk menetapkan tinggi rendahnya spread. Dalam praktek perbankan di Indonesia, eksekutif bank menetapkan spread (net margin) sebesar $2 \%$ hingga $3 \%$ p.a. yang merupakan harga yang layak (cukup) sebagai komponen dari lending rate.

\section{II.2.5. Pajak}

Pembebanan pajak sebagai komponen dari penentuan tingkat bunga kredit (lending rate) dapat dibebankan penuh atau sebagian, tergantung pada kebijakan bank yang bersangkutan dalam menghadapi persaingan.

\section{METODOLOGI PENELITIAN DAN SPESIFLKASI MODEL}

\section{III.1. Metodologi Penelitian}

Tulisan ini merupakan perluasan jangkauan variabel baik dari dalam negeri maupun luar negeri. Data yang digunakan adalah data time series pada kurun waktu tahun 1983 sampai dengan 2002. Adapun metode analisis yang digunakan untuk mengestimasi model penelitian dua analisis yaitu analisis jangka panjang dengan menggunakan persamaan kointegrasi dan analisis dinamis jangka pendek dengan menggunakan ECM (Error Correction Model)

Konsep terkini yang banyak dipakai untuk menguji kestasioneran data runtun waktu adalah uji akar unit (unit root test) atau dikenal juga dengan uji Dickey Fuller (DF) dan uji Augmented Dickey Fuller. Jika semua variabel lolos dari uji akar unit, maka selanjutnya dilakukan uji kointegrasi (cointegrati test) untuk mengetahui kemungkinan terjadinya keseimbangan atau kestabilan jangka panjang diantara variabel - variabel yang diamati. Sedangkan untuk mengetahui pengaruh jangka pendek digunakan metode ECM (Error Correction Model). 


\section{III.2. Spesifikasi Model}

Metode ini adalah suatu regresi tunggal menghubungkan diferensi pertama pada variabel bebas $\left(\mathrm{Dy}_{\mathrm{t}}\right)$ dan tingkatan variabel yang dimundurkan (dagged level variables $=\mathrm{X}_{\mathrm{t}-1}$ ) untuk semua variabel dalam model. Metode ini dikembangkan oleh Engel dan Granger pada tahun 1987. Bentuk umum metode ECM adalah sebagai berikut (Insukindro,1991:134):

$D Y_{t}=r_{0}+r_{1} D X_{1 t}+r_{2} D X_{2 t}+r_{3} B X_{1 t}+r_{4} B X_{2 t}+r_{5}\left(B X_{1 t}+B X_{2 t}-B Y_{t}\right)$

Untuk mengetahui spesifikasi model dengan ECM merupakan model yang valid, dapat terlihat pada hasil uji statistik terhadap koefisien ECT. Jika hasil pengujian terhadap koefisien ECT signifikan, maka spesifikasi model yang diamati valid.

$R_{t}=f\left(S_{B}, J U B_{t}, I N F_{t}, S B I_{t}, P D B_{t}, e_{t}\right)$

$\mathrm{DR}_{\mathrm{t}}=\mathrm{bo}+\mathrm{b}_{1} \mathrm{DSIB}_{\mathrm{t}}+\mathrm{b}_{2} \mathrm{DJUB}_{\mathrm{t}}+\mathrm{b}_{3} \mathrm{DINF}_{\mathrm{t}}+\mathrm{b}_{4} \mathrm{DSBI}_{\mathrm{t}}+\mathrm{b}_{5} \mathrm{DPDB}_{\mathrm{t}}+\mathrm{b}_{6} \mathrm{SIB}_{\mathrm{t}-1}+\mathrm{b}_{7} \mathrm{JUB}_{\mathrm{t}-1}+$

$b_{8} I N F_{t-1}+b_{9} S B I_{t-1}+b_{10} P D B_{t-1}+b_{11}\left(S B_{t-1}+J U B_{t-1}+I N F_{t-1}+S B I_{t-1}+P D B_{t-1}\right)$

Keterangan :

$\mathrm{R}_{\mathrm{t}} \quad=$ Tingkat suku bunga pinjaman pada periode $\mathrm{t}$

$\mathrm{SIB}_{\mathrm{t}}=$ Singapore Inter Bank Offer Rate pada periode $\mathrm{t}$

$\mathrm{INF}_{\mathrm{t}}=$ Tingkat inflasi pada periode $\mathrm{t}$

$\mathrm{JUB}_{\mathrm{t}}=$ Jumlah uang beredar pada periode $\mathrm{t}$

$\mathrm{SBI}_{\mathrm{t}}=$ Tingkat bunga Sertifikat Bank Indonesia periode $\mathrm{t}$

$\mathrm{PDB}_{\mathrm{t}}=$ Produk Domestik Bruto pada periode $\mathrm{t}$

$\mathrm{e}_{\mathrm{t}}=$ Error distribunce pada periode $\mathrm{t}$

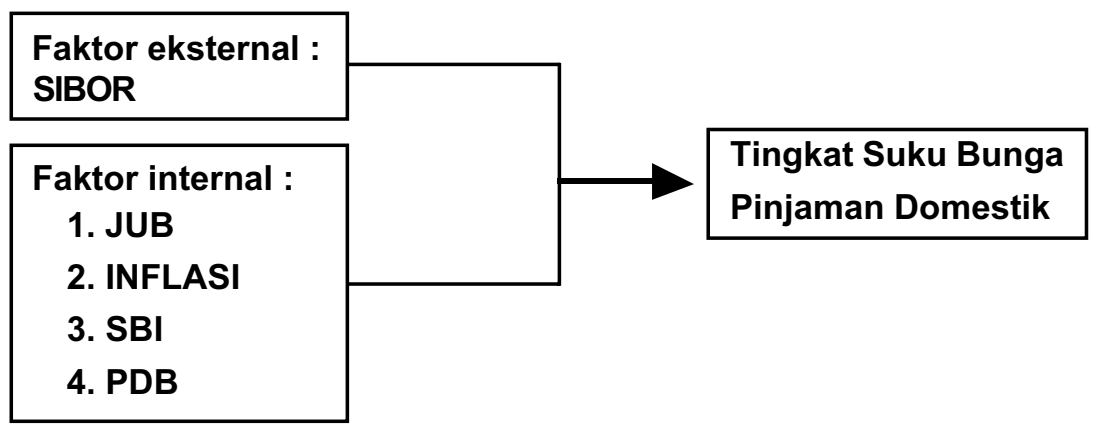

Kerangka Konseptual 
Faktor-faktor yang mempengaruhi tingkat bunga pinjaman dapat dibagi menjadi 2, yaitu faktor eksternal dan faktor internal. Faktor eksternal terdapat variabel SIBOR (Singapore Inter Bank Offer Rate), karena secara umum tingkat bunga internasional terutama di Asia Tenggara yang sering dipakai adalah tingkat bunga SIBOR. Dalam penelitian ini akan diketahui apakah faktor eksternal tersebut berpengaruh secara signifikan terhadap tingkat bunga pinjaman di Indonesia.

\section{PEMBAHASAN DAN HASIL ESTIMASI}

\section{IV.1. Pengujian akar-akar Unit (Unit Root Test)}

Pengujian akar-akar unit untuk semua variabel yang digunakan dalam analisis runtun waktu perlu dilakukan untuk memenuhi kesahihan analisis ECM (Error Correction Model). Ini berarti bahwa data yang dipergunakan harus bersifat stasioner, atau dengan kata lain perilaku data yang stasioner memiliki varians yang tidak terlalu besar dan mempunyai kecenderungan untuk mendekati nilai rata-ratanya.

Pengujian stasioneritas data yang dilakukan terhadap seluruh variabel dalam model penelitian yang penulis ajukan, didasarkan pada Augmented Dickey Fuller Test, yang perhitungannya menggunakan bantuan komputer program E-Views 3.0. hasil pengujian dapat dilihat pada Tabel 4.1. dibawah ini.

\begin{tabular}{|c|c|c|c|c|}
\hline \multirow{3}{*}{ Variabel } & $\begin{array}{r}\text { Tabel } 4.1 \text { Nila } \\
\text { nented Dickey Fulle }\end{array}$ & $\begin{array}{l}\text { sionerit } \\
\text { unakan }\end{array}$ & $\begin{array}{l}n \\
\text { (Uji DF) }\end{array}$ & 100 \\
\hline & \multirow{2}{*}{$\begin{array}{c}\text { Nilai Hitung Mutlak } \\
\text { DF }\end{array}$} & \multicolumn{3}{|c|}{ Nilai Kritis Mutlak Mc Kinnon } \\
\hline & & $10 \%$ & $5 \%$ & $1 \%$ \\
\hline $\mathrm{DR}$ & 4,230781 & 2,6672 & 3,0521 & 3,8877 \\
\hline DSIB & 4,681423 & 2,6672 & 3,0521 & 3,8877 \\
\hline DJUB & 5,214849 & 2,6672 & 3,0521 & 3,8877 \\
\hline DINF & 4,097102 & 2,6672 & 3,0521 & 3,8877 \\
\hline DSBI & 4,716317 & 2,6672 & 3,0521 & 3,8877 \\
\hline DPDB & 5,547550 & 2,6672 & 3,0521 & 3,8877 \\
\hline
\end{tabular}

Pada Tabel 4.1 dan 4.2 menunjukkan bahwa pada ordo nol semua data sudah berada pada kondisi stasioner. Karena nilai hutang mutlak DF dan ADF dari masing-masing variabel lebih besar dari nilai kritis mutlak Mc Kinnon pada tingkat $\alpha 10 \%$. Hal ini berarti bahwa distribusi ( $\mathrm{t}$ ) mengarah pada kondisi yang signifikan dengan menggunakan uji stasioneritas metode DF maupun ADF (tabel 4.2). 
Tabel 4.2 Nilai Uji Stasioneritas Dengan

Metode Augmented Dickey Fuller Menggunakan Trend \& Intersep (Uji ADF) Pada Ordo 0

\begin{tabular}{|c|c|c|c|c|}
\hline \multirow{2}{*}{ Variabel } & Nilai Hitung Mutlak & \multicolumn{3}{|c|}{ Nilai Kritis Mutlak Mc Kinnon } \\
\hline & ADF & $10 \%$ & $5 \%$ & $1 \%$ \\
\hline $\begin{array}{l}\text { DR } \\
\text { DSIB } \\
\text { DJUB } \\
\text { DINF } \\
\text { DSBI } \\
\text { DPDB }\end{array}$ & $\begin{array}{l}5,207418 \\
5,685077 \\
5,215012 \\
5,007383 \\
5,570302 \\
5,425640\end{array}$ & $\begin{array}{l}3,2964 \\
3,2964 \\
3,2964 \\
3,2964 \\
3,2964 \\
3,2964\end{array}$ & $\begin{array}{l}3,7119 \\
3,7119 \\
3,7119 \\
3,7119 \\
3,7119 \\
3,7119\end{array}$ & $\begin{array}{l}4,6193 \\
4,6193 \\
4,6193 \\
4,6193 \\
4,6193 \\
4,6193\end{array}$ \\
\hline
\end{tabular}

\section{IV.2. Pengujian Kointegrasi (Cointegrasi Test)}

Setelah uji stasioneritas melalui uji akar-akar unit dan derajat integrasi dipenuhi, maka langkah selanjutnya adalah melakukan uji kointegrasi, untuk mengetahui parameter jangka panjang. Uji statistik yang sering dipakai adalah uji CRDW (Cointegrating Regression Durbin Watson), uji DF dan uji ADF. Namun, dalam penelitian ini digunakan metode Engel dan Granger untuk menguji kointegrasi variabel-variabel yang ada, dengan memakai uji statistik DF dan ADF untuk melihat apakah residual regresi kointegrasi stasioner atau tidak. Untuk menghitung nilai DF dan ADF terlebih dahulu adalah membentuk persamaan regresi kointegrasi dengan metode kuadrat terkecil biasa (OLS). Hasil akhir dari pengolahan uji kointegrasi ini ditunjukkan oleh tabel 4.3 dan 4.4 sebagai berikut :

\begin{tabular}{|c|c|c|c|c|}
\hline \multirow{2}{*}{\multicolumn{5}{|c|}{$\begin{array}{r}\text { Tabel 4.3. Regresi } \\
\text { Menggunakan Estimasi OLS dengan ve } \\
\text { Variabel Dependen : Suku Bunga Pinjaman }\end{array}$}} \\
\hline & & & & \\
\hline Variabel & Koefisien & $\begin{array}{l}\text { Standar } \\
\text { Error }\end{array}$ & $\begin{array}{l}\text { t- } \\
\text { Hitung }\end{array}$ & $\begin{array}{c}\text { Tingkat } \\
\text { Signifikan }\end{array}$ \\
\hline $\begin{array}{l}\text { Konstanta } \\
\text { DSIBOR } \\
\text { DLn-JUB } \\
\text { DINF } \\
\text { DSBI } \\
\text { DLn-PDB } \\
\text { SIBOR (-1) } \\
\text { Ln-JUB (-1) } \\
\text { INFLASI (-1) } \\
\text { SBI (-1) } \\
\text { Ln-PDB (-1) }\end{array}$ & $\begin{array}{r}0,477521 \\
0,152652 \\
4,768627 \\
-0,427520 \\
0,278416 \\
-0,088556 \\
0,352910 \\
0,479400 \\
0,415855 \\
-0,524223 \\
0,812240\end{array}$ & $\begin{array}{l}0,158596 \\
0,047955 \\
0,106527 \\
0,106190 \\
0,118854 \\
4,251347 \\
0,115970 \\
1,986301 \\
0,637261 \\
0,141791 \\
0,193379\end{array}$ & $\begin{array}{r}3,010918 \\
3,183232 \\
4,476412 \\
-4,449768 \\
2,342499 \\
-0,020830 \\
-3,043109 \\
-0,241353 \\
-0,625566 \\
-3,697138 \\
4,201160\end{array}$ & $\begin{array}{r}0,0483 \\
0,0472 \\
0,0231 \\
0,0253 \\
0,0517 \\
0,984 \\
0,0470 \\
0,8162 \\
0,5349 \\
0,0338 \\
0,0249\end{array}$ \\
\hline $\begin{array}{l}\mathrm{R}^{2} \\
\mathrm{~F} \text { Statistik } \\
\text { DW Statistik }\end{array}$ & \multicolumn{4}{|l|}{$\begin{array}{l}: 0,922879 \\
: 7,615138 \\
: 1,995171\end{array}$} \\
\hline
\end{tabular}




\begin{tabular}{|c|c|c|c|c|}
\hline \multicolumn{5}{|c|}{$\begin{array}{l}\text { Tabel 4.4. Nilai Uji Stasioneritas dengan } \\
\text { Metode Augmented Dickey Fuller pada Ordo } 0 .\end{array}$} \\
\hline Nilai Hitung ADF : & $-5,678989$ & \multicolumn{2}{|c|}{$\begin{array}{l}\text { 1\% Nilai Kritis Mc Kinnon } \\
5 \% \text { Nilai Kritis Mc Kinnon } \\
10 \% \text { Nilai Kritis Mc Kinnon }\end{array}$} & $\begin{array}{r}-3,88877 \\
-3,0521 \\
-2,6672\end{array}$ \\
\hline \multicolumn{5}{|c|}{ Variabel Dependen : D(Residu) } \\
\hline Variabel & Koefisien & $\begin{array}{l}\text { Standar } \\
\text { Error }\end{array}$ & $\begin{array}{c}\text { t- } \\
\text { Hitung }\end{array}$ & $\begin{array}{c}\text { Tingkat } \\
\text { Signifikan }\end{array}$ \\
\hline $\begin{array}{l}\text { Residu (-1) } \\
\text { D(Residu(-1) }\end{array}$ & $\begin{array}{r}-1,481732 \\
0,219353\end{array}$ & $\begin{array}{l}0,402755 \\
0,263037\end{array}$ & $\begin{array}{r}-3,678989 \\
0,833924\end{array}$ & $\begin{array}{l}0,0025 \\
0,4183\end{array}$ \\
\hline $\begin{array}{l}\mathrm{R}^{2} \\
\text { F Statistik } \\
\text { DW Statistik }\end{array}$ & \multicolumn{4}{|l|}{$\begin{array}{l}: 0,629136 \\
: 11,87483 \\
: 1,924922\end{array}$} \\
\hline
\end{tabular}

Dari regresi kointegrasi sebagaimana ditunjukan pada Tabel 4.3 didapatkan nilai residunya, kemudian nilai residu tersebut diuji menggunakan metode Augmented Dickey Fuller untuk melihat apakah nilai residual tersebut stasioner atau tidak, pengujian ini sangat penting apabila model dinamis akan dikembangkan. Tabel 4.4 menunjukkan bahwa nilai residu yang didapat ternyata stasioner pada ordo 0 , hal ini terlihat dari nilai hitung mutlak ADF lebih besar dari nilai kritis mutlak Mc Kinnon pada $\alpha 1 \%$, maka langkah selanjutnya adalah melakukan perbandingan model fungsi yaitu (1). Model ECM dengan menggunakan transformasi bentuk natural logaritma (Ln), (2). Model fungsi ECM tanpa menggunakan transformasi bentuk natural logaritma (Ln).

\section{IV.3. Perbandingan Model}

Hasil pengolahan data masing-masing model dari hasil print out komputer dapat dilihat pada Tabel 4.5. sebagai berikut : 


\begin{tabular}{|c|c|c|c|c|c|c|}
\hline \multirow{3}{*}{ Variabel } & \multicolumn{5}{|c|}{ Komparasi Hasil Dengan Pendekatan Model ECM } & \\
\hline & \multicolumn{3}{|c|}{ Regresi Linier I (tanpa Ln) } & \multicolumn{3}{|c|}{ Regresi Linear II (dengan Ln) } \\
\hline & Koefisien & Std. Error & Prob.sig. & Koefisien & Std. Error & Prob.sig. \\
\hline $\mathrm{C}$ & 17,056090 & 9,043426 & 0,1013 & 0,477521 & 0,158596 & $0,0483^{*}$ \\
\hline DSIBOR & $-0,181846$ & 0,808320 & 0,8284 & 0,152652 & 0,047955 & $0,0472^{*}$ \\
\hline DJUB & 0,187171 & 0,276148 & 0,5197 & 4,768627 & 0,106527 & $0,0231^{*}$ \\
\hline Dinflasi & 0,027674 & 0,100695 & 0,7914 & $-0,472520$ & 0,106190 & 0,0253 \\
\hline DSBI & 1,241643 & 0,123983 & $0,0001^{* *}$ & 0,278416 & 0,118854 & 0,0517 \\
\hline DPDB & 0,000014 & 0,000021 & 0,5175 & $-0,088556$ & 4,251347 & 0,9840 \\
\hline SIBOR (-1) & 0,295911 & 0,865625 & 0,7425 & $-0,352910$ & 0,115970 & 0,0470 \\
\hline $\operatorname{JUB}(-1)$ & $-0,917038$ & 0,024276 & $0,0451^{*}$ & 0,479400 & 1,986301 & 0,8162 \\
\hline Inflasi $(-1)$ & 2,306163 & 0,679822 & $0,0167^{*}$ & $-0,415855$ & 0,637261 & 0,5349 \\
\hline SBI (-1) & 0,566587 & 0,407530 & 0,2070 & $-0,524223$ & 0,141791 & 0,0338 * \\
\hline $\operatorname{PDB}(-1)$ & 0,000001 & 0,000018 & 0,9519 & 0,812420 & 0,193379 & 0,0249 * \\
\hline ECT & $-0,380350$ & 0,626128 & 0,5627 & 0,394717 & 0,108183 & $0,0330^{*}$ \\
\hline R - Square & & & 0,8134 & & & 0,9229 \\
\hline Adj. R-Square & & & 0,7774 & & & 0,8017 \\
\hline F-statistik & & & 6,7139 & & & 7,6151 \\
\hline D- W statistik & & & 2,0204 & & & 1,9952 \\
\hline
\end{tabular}

Dari hasil pengolahan data tersebut maka untuk menentukan model mana yang terbaik terlebih dahulu dilakukan uji model.

Dalam melakukan uji model digunakan hipotesis sebagai berikut :

Ho : Model Regresi $1=$ model regresi 2

Ha : Model Regresi $1 \neq$ model regresi 2

Kemudian dilakukan pengujian secara statistik dengan rumus:

$$
\mathrm{Fh}=\frac{S S E_{1} / D f_{1}}{S S E_{2} / D f_{2}}
$$

Keterangan :

SSE1 : Sum Square Residual pada regresi I

SSE2 : Sum Square Residual pada regresi II

Df1 : Derajad bebas Sum Square Residual pada regresi I

Df2 : Derajad bebas Sum Square Residual pada regresi II 
Kemudian hasil dari hasil $\mathrm{F}$ hitung akan dibandingkan dengan hasil dari $\mathrm{F}$ tabel, dimana apabila $\mathrm{F}$ hitung > $\mathrm{F}$ tabel Ho ditolak Ha diterima artinya model regresi I berbeda dengan model regresi II sedangkan $\mathrm{F}$ hitung $<\mathrm{F}$ tabel maka Ho diterima Ha ditolak artinya model regresi I sama dengan model regresi II.

\begin{tabular}{l|c|c|c}
\multicolumn{2}{c}{ Tabel 4.6. } \\
\multicolumn{2}{c|}{ Tabel Analisis Varians } \\
\multicolumn{1}{|c|}{ Sumber } & regresi I & regresi II & F hitung \\
SSE & 79,69591 & 20,57573 & 3,8732 \\
Df & 12 & 12 & \\
\hline Sumber : Hasil Print Out Komputer, 2003.
\end{tabular}

Berdasarkan Tabel 4.6. di atas manunjukkan bahwa $\mathrm{F}$ hitung $>\mathrm{F}$ tabel yaitu 3,8732 $>1,782$ maka Ho ditolak Ha diterima pada taraf keyakinan $95 \%(\alpha=5 \%)$. Hal ini berarti bahwa model regresi I berbeda dengan model regresi II.

Berdasarkan perbandingan model dan uji model sebelumnya menunjukkan kedua model tersebut adalah benar-benar berbeda maka pemilihan model terbaik dilakukan dengan membandingkan kebaikan dan kelemahan dari masing-masing model baik secara teoritis maupun secara statistik (nilai $F$, nilai $\mathrm{R}^{2}$, dan $\mathrm{t}$ test). Pada tabel 4.5. hasil komparasi nilai statistik dari masing-masing model diketahui bahwa nilai $F$ hitung regresi II $>F$ hitung regresi I, yaitu 7,615138 $>6,713852$ dan nilai $R^{2}$ regresi II $>R^{2}$ regresi I, yaitu bernilai $0,922879>0,813422$. Berdasarkan hasil tersebut dapat disimpulkan bahwa nilai $F$ hitung dan $\mathrm{R}^{2}$ pendekatan model ECM dengan menggunakan transformasi bentuk natural logaritma lebih tinggi jika dibandingkan dengan model ECM biasa (tanpa Ln).

Berdasarkan uji t dengan taraf keyakinan 95\% diketahui bahwa pendekatan model ECM dengan transformasi natural logaritma secara kuantitatif lebih banyak variabel yang signifikan dibanding dengan tanpa menggunakan bentuk Ln. variabel independen yang signifikan dengan menggunakan bentuk Ln ada 6 variabel, yaitu 3 variabel jangka panjang meliputi : tingkat bunga internasional SIBOR, jumlah uang beredar, dan inflasi dan 3 variabel jangka pendek meliputi : bunga internasional SIBOR, Sertifikat Bank Indonesia, Produk Domestik Bruto sedangkan variabel independen yang signifikan tanpa menggunakan bentuk Ln ada 3 variabel, yaitu 1 variabel jangka panjang Sertifikat Bank Indonesia dan 2 variabel jangka pendek, meliputi : jumlah uang beredar dan inflasi.

Hasil perbandingan antara model tersebut menunjukkan bahwa 4 model terbaik untuk meneliti tingkat suku bunga pinjaman di Indonesia tahun 1983 - 2002 adalah model 
pendekatan ECM dengan bentuk Ln. model ini lebih baik dari model yang lain jika dilihat dari uji $F, R^{2}$, dan uji t-nya.

\section{IV.4. Analisis dengan ECM}

Pada penelitian ini model analisis yang digunakan adalah Model Koreksi Kesalahan atau Error Correction Model (ECM), secara lengkap dirumuskan sebagai berikut :

$D_{t}=0,478+0,153$ DSIB $_{t}+4,769$ DJUB $_{t}-0,473$ DINF $_{t}+0,278$ DSBI $_{t}-0,089$ DPDB $_{t}-0,353$ SIB $_{t-1}+$ $0,479 \mathrm{JUB}_{\mathrm{t}-1}-0,416 \mathrm{INF}_{\mathrm{t}-1}-0,524 \mathrm{SBI}_{\mathrm{t}-1}+0,812 \mathrm{PDB}_{\mathrm{t}-1}+0,394 \mathrm{ECT}$

Berdasarkan hasil perhitungan dengan analisis regresi linear ECM di atas, maka dapat diketahui nilai variabel ECT (Error Correction Term) yaitu variabel yang menunjukkan biaya keseimbangan tingkat suku bunga pinjaman. Hal ini dapat menjadikan indikator bahwa spesifikasi model baik atau tidak melalui tingkat signifikansi koefisien koreksi kesalahan (Insukindro, 1991 : 84). Jika variabel ECT signifikan pada tingkat signifikansi 5\% dan menunjukkan tanda positif, maka spesifikasi model sudah sahih (valid) dan dapat menjelaskan variasi variabel tak bebas.

Koefisien ECT menunjukkan angka 0,394 berarti bahwa proporsi biaya keseimbangan dan perkembangan tingkat suku bunga pinjaman pada periode sebelumnya yang disesuaikan pada periode sekarang adalah sekitar 0,394\%, sedangkan tingkat signifikansi ECT menunjukkan angka 0,0330 berarti signifikan pada $\alpha \leq 5 \%$. Hal ini berarti bahwa spesifikasi model yang dipakai adalah tepat dan mampu menjelaskan variasi dinamis. Variabel jangka pendek dari model persamaan tersebut ditunjukkan oleh $\operatorname{SIBOR}(-1)$, inflasi $(-1), \operatorname{SBI}(-1)$, $\operatorname{JUB}(-1)$, dan $\mathrm{PDB}(-1)$ sedangkan variabel jangka panjang dari model persamaan tersebut ditunjukkan DSIBOR, Dinflasi, DSBI, DJUB, dan DPDB. Koefisien regresi jangka pendek dari regresi ECM tingkat suku bunga pinjaman ditunjukkan oleh besamya koefisien pada variabel-variabel jangka pendek di atas sedangkan koefisien regresi jangka panjang dengan simulasi dari regresi ECM tingkat suku bunga pinjaman diperoleh dari :

Konstanta : $\beta_{0} / \beta_{12}=0,477521 / 0,394717=1,2098$

DSIBOR

$:\left(\beta_{1}+\beta_{12}\right) / \beta_{12}=(0,152662+0,394717) / 0,394717=1,3868$

DJUB

$:\left(\beta_{2}+\beta_{12}\right) / \beta_{12}=(4,768627+0,394717) / 0,394717=13,0811$

Dinflasi

$:\left(\beta_{3}+\beta_{12}\right) / \beta_{12}=(-0,472520+0,394717) / 0,394717=-2,1971$

DSBI

$$
:\left(\beta_{4}+\beta_{12}\right) / \beta_{12}=(0,278416+0,394717) / 0,394717=1,7054
$$

DPDB

$$
:\left(\beta_{5}+\beta_{12}\right) / \beta_{12}=(-0,088556+0,394717) / 0,394717=0,7756
$$


$\operatorname{SIBOR}(-1)$, inflasi (-1), SBI( -1), JUB( -1), dan PDB( -1) merupakan variabel yang menunjukkan parameter dalam jangka pendek. Sedangkan koefisien-koefisiennya menunjukkan besarnya pengaruh yang dilakukan pada penyesuaian variabel dependen terhadap perubahan variabel independen dalam jangka pendek. Misalnya DSIBOR( -1) yang memiliki koefisien sebesar 0,152652 ini berarti bahwa akan kenaikan tingkat suku bunga pinjaman sebesar 0,152652\% jika terjadi kenaikan pada suku bunga internasional SIBOR sebesar $1 \%$. Variabel DSIBOR, DJUB, Dinflasi, DSBI, dan DPDB merupakan variabel yang menunjukkan parameter jangka panjang. Hal ini berarti jika ECT-nya signifikan pada tingkat signifikansi 5\% maka ada hubungan antara ECM dan uji kointegrasi, sehingga koefisien regresi variabel jangka panjang merupakan besarnya kekuatan pengaruh variabel dependen oleh perubahan pada variabel independen dalam jangka panjang dan merupakan koefisien asli. Karena pengaruh jangka panjang juga bisa dilihat pada koefisien kointegrasi jika ECT signifikan, maka besamya koefisien regresi variabel jangka panjang pada ECM dengan kointegrasi menunjukkan parameter yang hampir sama.

\section{IV.5. Uji Statistik dan Ekonometrik}

Uji F ini digunakan untuk menguji variabel independen secara keseluruhan dan bersama-sama, untuk melihat apakah variabel independen secara keseluruhan mempengaruhi variabel dependen secara signifikan. Kriteria pengujian nilai $\mathrm{F}$ adalah jika $\mathrm{F}$ hitung $>\mathrm{F}$ tabel dengan taraf keyakinan 95\% maka Ho ditolak yang berarti bahwa ada pengaruh secara serempak atau secara bersama-sama dari keseluruhan variabel independen terhadap variabel dependen. Sebaliknya jika $F$ hitung $<F$ tabel maka Ho diterima yang berarti bahwa tidak ada pengaruh secara serempak atau secara bersama-sama dari keseluruhan variabel independen terhadap variabel dependen. Nilai $F_{\text {hitung }}$ adalah 7,615138 dengan probabilitas sebesar 0,006397 . Sedangkan nilai $F_{\text {tabel }}$ dengan tingkat signifikansi $\leq 5 \%$ $20-13=7 ; 12$ adalah 4,46. Karena $F_{\text {hitung }}>F_{\text {tabel, }}$, maka Ho ditolak dan Ha diterima. Hal ini berarti secara bersama-sama faktor jangka pendek dan jangka panjang tingkat bunga internasional SIBOR, jumlah uang beredar, inflasi, Sertifikat Bank Indonesia, dan Produk Domestik Bruto mempunyai pengaruh yang signifikan / nyata terhadap tingkat suku bunga pada derajat signifikansi $\leq 5 \%$.

Uji determinasi untuk mengetahui berapa persen perubahan variasi variabel independen dapat menjelaskan oleh perubahan variasi variabel dependen. Berdasarkan hasil etimasi menunjukkan bahwa nilai $R^{2}$ adalah sebesar 0,922879 yang berarti $92,2879 \%$ faktor jangka pendek dan jangka panjang tingkat bunga internasional SIBOR, jumlah uang beredar, inflasi, Sertifikat Bank Indonesia dan Produk Domestik Bruto dapat menjelaskan 
variasi perubahan tingkat suku bunga pinjaman sedangkan sisanya $7,7121 \%$ dipengaruhi diluar model.

Uji multikolinieritas digunakan metode Klein yang dikemukakan oleh L.R. Klein. Metode ini membandingkan lower case (korelasi antar masing-masing variabel independen). Jika $R^{2} y X_{i}, X_{j}, \ldots X_{n}>r^{2} X_{i}, X_{j}$ maka tidak terjadi masalah multikolinieritas. Hasil uji Klein untuk mendeteksi masalah multikolinieritas menunjukkan bahwa untuk semua korelasi antar variabel bebas memiliki $r^{2}$ yang lebih kecil dari $R^{2}\left(r^{2}<R^{2}\right)$. Hal ini memberi kesimpulan bahwa semua variabel bebas dalam spesifikasi model yang digunakan terlepas dari masalah multikolinieritas.

Heteroskedastisitas terjadi jika gangguan muncul dalam fungsi regresi yang mempunyai varian yang tidak sarna, sehingga penaksir OLS tidak efisien baik dalam sampel kecil maupun sampel besar. Untuk mendeteksi ada atau tidaknya masalah Heteroskedastisitas adalah dengan menggunakan Uji Glejser. Adapun tahap-tahap dalam Uji Glejser yaitu :

(1) Lakukan regresi terhadap model yang digunakan

(2) Setelah mendapatkan nilai residual $e_{i}$ dan regresi OLS, selanjutnya regresikan nilai absolut $e_{i},\left|e_{i}\right|$, terhadap variabel $X$ yang diduga mempunyai hubungan erat dengan $\sigma_{i}^{2}$

Model $\left|e_{i}\right|=\beta_{0}+\beta i X i+U i$

dimana :

$\left|e_{i}\right|=$ Nilai absolut residual.

$\mathrm{Xi} \quad=$ Variabel penjelas.

Ui = Variabel penggangu.

Hipotesis yang digunakan :

Ho : $\beta \mathrm{i}=0$ (Tidak Ada Masalah Heteroskedastisitas)

$\mathrm{Ha}: \beta \mathrm{i} \neq 0$ (Ada Masalah Heteroskedastisitas)

Apabila $t_{\text {hitung }}>\mathrm{t}_{\text {tabel }}$, maka Ho ditolak dan Ha diterima, berarti ada masalah heteroskedastisitas. Sedangkan jika $t_{\text {hitung }}<t_{\text {tabel }}$, maka Ho diterima dan Ha ditolak berarti tidak ada masalah heteroskedastisitas / homokedastisitas (Gujarati, 1991: 177). Untuk lebih jelasnya dapat dilihat pada Tabel 4.7 sebagai berikut : 


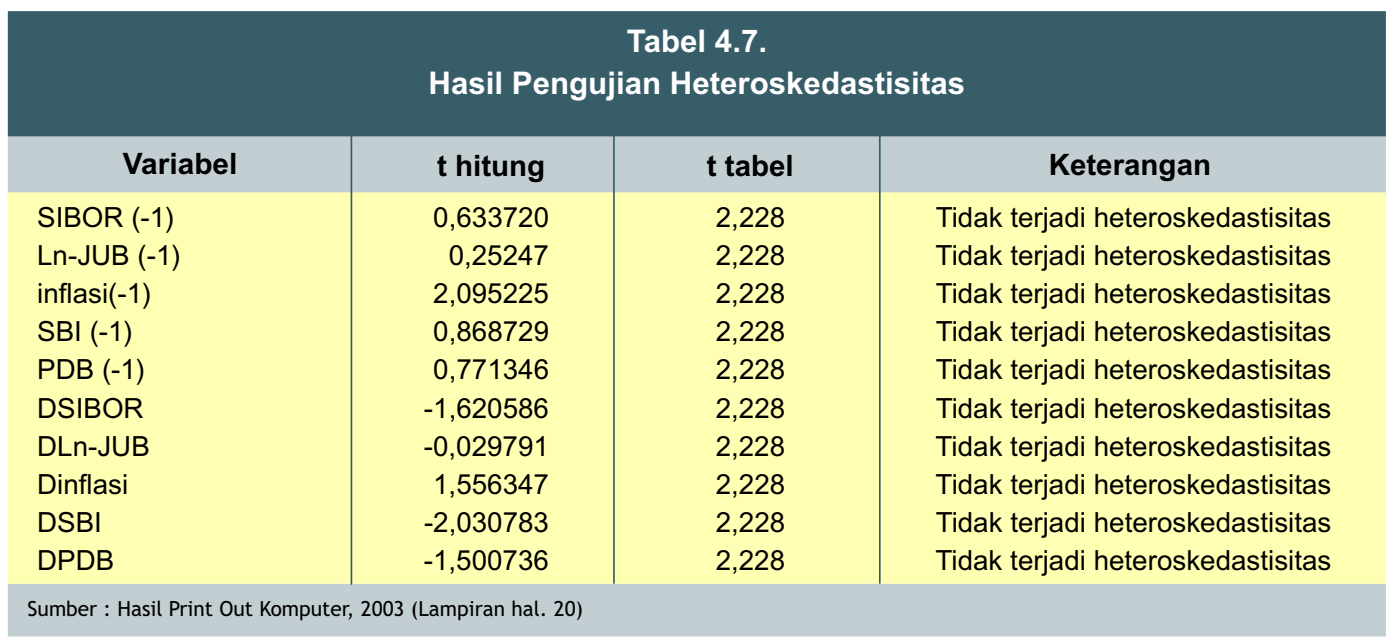

Berdasarkan Tabel 4.7. di atas menunjukkan bahwa semua variabel mempunyai distribusi t hitung < $t$ tabel, ini berarti bahwa Ho diterima Ha ditolak sehingga dapat disimpulkan bahwa model yang dipakai terhindar dari masalah heteroskedastisitas pada tingkat keyakinan $95 \%(\alpha=5 \%)$.

Autokorelasi untuk model dinamis, seperti ECM percobaan d tidak bisa digunakan untuk menguji ada tidaknya autokorelasi, karena DW statistik secara asimtotik akan biasa mendekati nilai 2 (Sritua Arief, 1993 : 15). Oleh karena alasan tersebut maka digunakan langrange Multiplier Test, yakni berupa regresi atas semua variabel bebas dalam persamaan regresi ECM tersebut dan variabel lag $t$ dari nilai residual regresi ECM. Adapun hasil persamaan regresi ECM dapat dituliskan sebagai berikut :

$$
\begin{aligned}
\text { Resid }_{i}= & \mathrm{bo}+\mathrm{b}_{1} \text { DSIB }_{\mathrm{t}}+\mathrm{b}_{2} \text { DJUB }_{\mathrm{t}}+\mathrm{b}_{3} \text { DINF }_{\mathrm{t}}+\mathrm{b}_{4} \text { DSBI }_{\mathrm{t}}+\mathrm{b}_{5} \text { DPDB }_{\mathrm{t}}+\mathrm{b}_{6} \text { SIB }_{\mathrm{t}-1}+\mathrm{b}_{7} \mathrm{JUB}_{\mathrm{t}-1}+ \\
& \mathrm{b}_{8} \mathrm{INF}_{\mathrm{t}-1}+\mathrm{b}_{9} \text { SBI }_{\mathrm{t}-1}+\mathrm{b}_{10} \text { PDB }_{\mathrm{t}-1}+\mathrm{b}_{11} \text { ECT }+\mathrm{b}_{12} \text { Resid }_{\mathrm{t}-1}
\end{aligned}
$$

Dari model tersebut akan didapat nilai $\mathrm{R}^{2}$, kemudian nilai ini dimasukkan dalarn rumus sebagai berikut : (n-1)R $R^{2}$, dimana $n$ adalah jumlah observasi, kemudian dilakukan pengujian dengan hipotesa sebagai berikut :

Ho : $\rho=0$ berarti tidak ada masalah autokorelasi

Ho : $\rho \neq 0$ berarti ada masalah autokorelasi

Selanjutnya nilai $(n-1) R^{2}$ diperbandingkan dengan $X^{2}(0,05)$. Dimana $X^{2}(0,05)$ adalah nilai kritis Chi Square yang ada dalam tabel statistik Chi Square. Jika (n-1)R $R^{2}$ lebih besar dari $\mathrm{X}^{2}$, maka terdapat masalah autokorelasi, dan jika sebaliknya maka tidak terjadi masalah autokorelasi. 
Hasil perhitungan Lagrange Multiplier Test dari persamaan tersebut dengan prograrn E-Views ditunjukkan oleh Tabel 4.8, sebagai berikut :

\begin{tabular}{|c|c|c|c|c|}
\hline \multicolumn{5}{|c|}{$\begin{array}{c}\text { Tabel 4.8. } \\
\text { Hasil Lagrange Multiplier Test Autokorelasi }\end{array}$} \\
\hline Variabel & Koefisien & std.error & t hitung & Signifikansi \\
\hline $\begin{array}{l}\text { C } \\
\text { DSIBOR } \\
\text { DLn-JUB } \\
\text { Dinflasi } \\
\text { DSBI } \\
\text { DLn-PDB } \\
\text { SIBOR (-1) } \\
\text { Ln-JUB (-1) } \\
\text { Inflasi }(-1) \\
\text { SBI (-1) } \\
\text { Ln-PDB (-1) } \\
\text { resid (-1) }\end{array}$ & $\begin{array}{r}-20,972870 \\
-0,788664 \\
-2,971439 \\
0,051435 \\
-0,177742 \\
-2,469448 \\
0,500600 \\
0,001642 \\
1,027399 \\
0,447745 \\
2,261049 \\
0,143618\end{array}$ & $\begin{array}{r}25,162700 \\
0,406071 \\
6,031141 \\
0,061996 \\
0,168234 \\
2,388612 \\
0,442542 \\
1,203113 \\
0,377182 \\
0,452004 \\
2,152543 \\
0,221432\end{array}$ & $\begin{array}{r}-0,833490 \\
-1,942218 \\
-0,492683 \\
0,829645 \\
-1,604898 \\
-1,033842 \\
1,310746 \\
0,001350 \\
0,003113 \\
1,945606 \\
1,050408 \\
0,648588\end{array}$ & $\begin{array}{l}0,4321 \\
0,0932 \\
0,6373 \\
0,4341 \\
0,1352 \\
0,3356 \\
0,2313 \\
0,9999 \\
0,9987 \\
0,2215 \\
0,3284 \\
0,5373\end{array}$ \\
\hline \multicolumn{5}{|c|}{ Variabel dependen : resid } \\
\hline $\begin{array}{l}\text { R Square } \\
\text { adj. R Square } \\
\text { D-W Statistik }\end{array}$ & & $\begin{array}{l}0,119987 \\
0,109967 \\
2,230452\end{array}$ & & \\
\hline
\end{tabular}

Dari Tabel 4.8 besarnya $R^{2}$ adalah 0,108876 , sehingga $(n-1) R^{2}=(20-1) 0,119987$ yang hasilnya adalah 2.279753 Sedangkan $X^{2}(12)$ dengan $\alpha$ sebesar $5 \%$ atau nilai kritis Chi-square $X^{2}(12)$ dan $\alpha=0,05$ adalah 21,026 sehingga dalam hal ini $(n-1) R^{2}<X^{2}$ maka Ho $: \rho=0$, diterima, dengan kata lain tidak terjadi masalah autokorelasi pada model analisis fungsi tingkat suku bunga pinjaman tersebut.

\section{IV.6. Interpretasi Secara Ekonomi}

Berdasarkan hasil estimasi data bahwa dalam model ECM dengan transformasi natural logaritma terdapat nilai konstanta sebesar 0,477521 berarti bahwa jika semua nilai variabel penjelas konstan maka rata-rata tingkat suku bunga pinjaman di Indonesia adalah sebesar 0,477521 poin. Interpretasi hasil penyesuaian jangka pendek dan jangka panjang variabel indeks saham sektor keuangan terhadap variabel-variabel penjelasnya dengan menggunakan model regresi linier ECM akan dijelaskan dibawah ini :

\section{Tingkat Bunga Internasional SIBOR}

Hasil perhitungan menunjukkan koefisien SIBOR jangka pendek sebesar 0,352910 ini berarti bahwa akan terjadi peningkatan tingkat bunga pinjaman sebesar $0,352910 \%$ bila 
terjadi kenaikan pada tingkat bunga internasional SIBOR sebesar 1\%. Dalam jangka pendek, pengaruh variabel ini bersifat inelastic terhadap tingkat bunga pinjaman. Kebijakan pemerintah Indonesia dalam mengendalikan tingkat suku bunga tergantung dengan keadaan dan kondisi perekonomian dunia. Reaksi yang cepat terhadap perubahan kondisi tingkat suku bunga internasional SIBOR akan mengurangi pelarian modal dari dalam negeri dalam jumlah yang besar. Ketika tingkat suku bunga pinjaman di luar negeri mengalami peningkatan maka para investor akan cenderung memanfaatkan dana yang ada di dalam negeri. Sedangkan hasil perhitungan jangka panjang sebesar - 0,181846 ini terjadi hubungan terbalik, yaitu bahwa akan terjadi penurunan tingkat bunga pinjaman di Indonesia sebesar $0,181846 \%$ bila terjadi kenaikkan pada tingkat bunga internasional SIBOR sebesar $1 \%$. Dalam jangka panjang, pengaruh variabel ini bersifat inelastic.

\section{Jumlah uang beredar}

Hasil perhitungan jangka panjang sebesar- 0,187171 ini terjadi hubungan terbalik, yaitu bahwa akan terjadi penurunan tingkat bunga pinjaman di Indonesia sebesar $0,187171 \%$ bila terjadi kenaikkan pada jumlah uang beredar sebesar $1 \%$. Dalam jangka panjang, pengaruh variabel ini bersifat inelastic. Keadaan ini dapat dijelaskan dimana ketika terjadi krisis ekonomi yang melanda Indonesia yang diikuti dengan krisis perbankan telah menyebabkan penarikan dana perbankan besar-besaran (banks run), karena kepercayaan masyarakat yang rendah terhadap perbankan. Masyarakat lebih tenang dan senang untuk memegang uang guna keperluan konsumsi akibat kenaikkan harga barang pokok atau menempatkan dananya dalam bentuk investasi yang lain. Keengganan masyarakat untuk menempatkan dananya dalam perbankan membuat JUB/MI di masyarakat menjadi meningkat yang ditandai dengan JUB pada tabun 1998 sebesar 101,20 Milyar rupiah atau dengan kenaikkan 29,18\% dari tahun sebelumnya, terutama periode sebelum krisis. Untuk mengurangi jumlah uang beredar, maka otoritas moneter menetapkan kebijakan moneter ketat yang ditandai dengan kenaikkan suku bunga SBI.

\section{$\underline{\text { 3. Inflasi }}$}

Hasil perhitungan jangka panjang sebesar 0,027674 ini berarti bahwa akan terjadi peningkatan tingkat bunga pinjaman di Indonesia sebesar 0,027674 bila terjadi kenaikkan pada inflasi sebesar $1 \%$. Dalam jangka panjang, pengaruh variabel ini bersifat inelastic. Artinya semakin tinggi tingkat inflasi maka mengakibatkan suku bunga simpanan akan naik, maka otomatis tingkat bunga pinjaman akan lebih tinggi. Tingkat bunga nominal yang lebih rendah dari pada angka laju inflasi membuat masyarakat enggan menaruh 
dananya dalam sektor perbankan serta menyebabkan terjadinya tingkat suku bunga riil yang negatif.

Untuk merangsang mobilisasi, menurut Mc Kinnon (1987) tingkat bunga riil harus positif sehingga tingkat bunga nominal harus lebih tinggi dari laju inflasi. Laju inflasi termasuk dalam faktor ekspektasi. Bilamana ekspektasi terhadap inflasi diperhitungkan sebagai faktor pengurangan tingkat bunga riil yang lebih rendah dari tingkat bunga riil di luar negeri, maka para deposan akan lebih tertarik untuk menempatkan dananya di luar negeri.

\section{Suku Bunga Sertifikat Bank Indonesia}

Hasil perhitungan menunjukkan koefisien Sertifikat Bank Indonesia jangka pendek sebesar 0,566587 ini berarti bahwa akan terjadi peningkatan tingkat bunga pinjaman sebesar $0,566587 \%$ bila terjadi kenaikan pada tingkat bunga SBI sebesar $1 \%$. Dalam jangka pendek, pengaruh variabel ini bersifat inelastic terhadap tingkat bunga pinjaman. Hal ini sesuai dengan teori bahwa kecenderungan tingginya suku bunga SBI akan diikuti oleh naiknya tingkat bunga simpanan dan otomatis meningkatkan bunga pinjaman. Tingkat bunga SBI merupakan referensi dari tingkat bunga deposito bank-bank umum. Akan tetapi kepercayaan masyarakat rendah terhadap dunia perbankan, kekhawatiran masyarakat akan rencana pembekuan bank dan adanya faktor-faktor sosial, politik dan keamanan yang akan datang menyebabkan masyarakat lebih tertarik untuk menaruh dananya di luar perbankan atau dipegang secara tunai. Keinginan masyarakat untuk tetap memegang uang secara tunai dananya membuat jumlah uang beredar tinggi.

\section{Produk Domestik Bruto}

Hasil perhitungan jangka panjang sebesar 1,241643 ini berarti bahwa akan terjadi peningkatan tingkat bunga pinjaman di Indonesia sebesar 1,241643\% bila terjadi kenaikkan pada tingkat bunga SBI sebesar $1 \%$. Dalam jangka panjang, pengaruh variabel ini bersifat elastic.Peningkatan tingkat suku bunga pinjaman sebagai akibat peningkatan Produk Domestik Bruto karena adanya lonjakan permintaan terhadap kredit pada perbankan. Dalam teori permintaan bahwa apabila jumlah permintaan meningkat terhadap suatu barang maka harga perolehan barang tersebut akan cenderung meningkat. Proses pertumbuhan ekonomi Indonesia akan membutuhkan banyak dana untuk menggerakan berbagai sektor dan perbankan yang menjadi salah satu penyangga moneter. 


\section{IV.7. Konsistensi temuan empirik dengan hipotesis}

Pada bagian ini akan terlihat konsistensi antara hasil penelitian temuan empirik dengan hipotesis yang telah diajukan sebagai kesimpulan.

\begin{tabular}{|c|c|c|c|c|c|c|}
\hline \multirow{4}{*}{ Variabel } & \multirow{3}{*}{\multicolumn{2}{|c|}{$\begin{array}{c}\text { Perbanding } \\
\text { Hipotesis }\end{array}$}} & \multicolumn{4}{|c|}{$\begin{array}{l}\text { Tabel } 4.9 . \\
\text { Hipotesis Dengan Temuan Empirik }\end{array}$} \\
\hline & & & & Temuan & Empirik & \\
\hline & & & \multicolumn{2}{|c|}{ Jangka Pendek } & \multicolumn{2}{|c|}{ Jangka Panjang } \\
\hline & Makna Statistik & Korelasi & Makna Statistik & Korelasi & Makna Statistik & Korelasi \\
\hline SIBOR & signifikan & + & signifikan & - & signifikan & + \\
\hline JUB & signifikan & + & tdk signifikan & + & signifikan & + \\
\hline INFLASI & signifikan & + & tdk signifikan & - & signifikan & - \\
\hline SBI & signifikan & + & signifikan & - & tdk signifikan & + \\
\hline PDB & signifikan & + & signifikan & + & tdk signifikan & - \\
\hline
\end{tabular}

Tabel 4.9. Memperlihatkan bahwa terdapat dua variabel yang menunjukkan konsistensi yang cukup baik antara hasil temuan empirik dengan hipotesis yang diajukan, yaitu variabel Produk Domestik Bruto dan jumlah uang beredar untuk periode jangka pendek sedangkan untuk periode jangka panjang terdapat 3 variabel yang konsisten yaitu variabel SIBOR, JUB, dan SBI menunjukkan hubungan yang positif. 


\section{DAFTAR PUSTAKA}

Anwar Nasution, 1991, Tinjauan Ekonomi Atas Dampak Paket Deregulasi Tahun 1988 Pada Sistem Keuangan Indonesia, PT Gramedia Pustaka Utama, Jakarta

Anonim, berbagai penerbitan. Indikator Ekonomi, Jakarta: Badan Pusat Statistik _ berbagai penerbitan. Laporan Tahunan Bank Indonesia, Jakarta : Bank Indonesia.

— Indonesia.

2000. “Mewaspadai Rayuan Produk Baru Bank”, Infobank, No. 275. Juni, Jakarta. , 1997. "Menebak Arus di Tengah Badai", warta ekonomi no 15/TH IX/I September, Jakarta.

Ascarya, 2002. Instrumen-instrumen Pengendalian Moneter, Seri Kebanksentralan. Jakarta : Pusat Pendidikan dan Studi Kebanksentralan, Bank Indonesia.

Boediono, 1980. Teori Moneter, Yogyakarta: BPFE-Yogyakarta.

Boediono, 1998. Ekonomi Moneter, Seri Sinopsis Pengantar IImu Ekonomi No.5, Yogyakarta : BPFE - UGM.

Boediono, 1991. Tingkat Bunga dan Faktor-Faktor Penentunya. Jurnal Ekonomi dan Bisnis Indonesia No.1 Tahun VI, 18 - 26.

Edward, Sebastian dan Mohsin S. Khan, 1985. Interest Rate Determination Independen Developing Countries, a Conceptual Framework, International Monetary Fund Staff Papper Volume 32, 123 - 134.

Goldfeld, Stephen M. dan Lester V. Chandler, 1990. Ekonomi Uang dan Bank, Jakarta: Penerbit Erlangga.

Insukindro, 1991. "Regresi Linear Lancung dalam Analisa Ekonomi : Studi Kasus Permintaan Deposito Dalam Valuta Asing di Indonesia”, Jurnal Ekonomi dan Bisnis Indonesia volume 1 No.1

Insukindro, 1994. Ekonomi Uang dan Bank, Yogyakarta: BPFE-Yogyakarta.

Iswardono SP, 1993. Uang dan Bank, Yogyakarta: BPFE-Yogyakarta. 
Gujarati, Damodar, 1995. Ekonometrika Dasar. Jakarta: Penerbit Erlangga.

Iswardono SP, 1999. Suku Bunga Diturunkan, Investasi Akan Meningkat? Jurnal Ekonomi dan Bisnis Indonesia Vol. 14 No.2, 34 - 42.

Judo Agung, 2000. Kinerja dan Fungsi Intermediasi Perbankan Pasca Krisis dan Otonomi Daerah, Buletin ekonomi dan moneter perbankan, september : 45 - 48.

Landerth, Harry, 1976. History Of Economic Theory, Boston: Houghton Mifflin company

Marihot B. Tambunan, 2002. Dua Viagra Disfungsi Intermediasi, Infobank, No. 270 vol. XXIV januari, Jakarta.

Muchdarsyah Sinungun, 1989. Uang dan Bank. Jakarta: Penerbit Bina Aksara.

Mulyanto, 1999. Teknik Kointegrasi dan Model Koreksi Kesalahan : Salah Satu Pemecahan Analisis Data Deret Waktu. Thesis S-2 Universitas Indonesia, Jakarta, tidak dipublikasikan

Nopirin, 1996. Ekonomi Moneter, Yogyakarta : BPFE- Yogyakarta.

OP. Simorangkir, 1989. Dasar-Dasar dan Mekanisme Perbankan, Edisi Revisi. Jakarta: Penerbit Aksara Persada Indonesia

Ramanathan, Ranu, 1992. Introductory Econometrics With Application, Second Edition, New York: Harcourt Brace Javanovich Inc

Sadono Sukirno, 2000. Makro Ekonomi Modern, Jakarta: Raja Grafindo Persada.

Sasongko Tedjo, 1994. Sekilas Ekonomi Indonesia, Jakarta: Penerbit Erlangga

Soewito, 1994. Sejarah Pemikiran Ekonomi : Teori Bunga, Ekonomi dan Keuangan Indonesia volume 32: 15 - 21.

Solikin dan Suseno, 2002. Uang: Pengertian, Penciptaan, dan Peranannya Dalam Perekonomian, Seri Kebanksentralan. Jakarta : Pusat Pendidikan dan Studi Kebanksentralan, Bank Indonesia

Solikin dan Suseno, 2002. Penyusunan Statistik Uang Beredar. Jakarta: Pusat Pendidikan dan Studi Kebanksentralan, Bank Indonesia

Solopos, Jum'at 27 Juni 2003. Bank Indonesia Mengimbau Kepada Perbankan Untuk menurunkan suku bunga Pinjamannya Berkaitan dengan terus Turunnya Sertifikat Bank Indonesia (SBI), Espos, Solo. 
Sritua Arif, 1993. Metodologi Penelitian Ekonomi, Yogyakarta : BPFE : UGM

Syamsudin Mahmud, 1985. Ekonomi Moneter Indonesia, Edisi Pertama. Jakarta: Yayasan Kesejahteraan Umat.

Tulus T.H. Tambunan, 1998. Penyebab Krisis Moneter di Indonesia, Jakarta : IKADIN Indonesia.

Umar Juoro, 1995. Pengaruh Pinjaman Luar Negeri dan PMA Terhadap Pertumbuhan Ekonomi Indonesia. Makalah Seri Dialog Politik Dalam Negeri ke -10, Jakarta : CIDES.

Y. Sri Susilo, dkk, 2000. Bank dan Lembaga Keuangan Non Bank, Jakarta: UI press 
